Debattinnlegg av

Christian Kock

\title{
Hvad er fornuftig uenighed?
}

Tidsskriftet Sakprosa

Volum 8, Nummer 1

(C) 2016 


\section{Hvad er fornuftig uenighed?}

"Fornuftig uenighed" kunne være nøgleordet for det syn på offentlig politisk debat som jeg har arbejdet ud fra i bogen De svarer ikke, og som Ida Andersen har forholdt sig kritisk og konstruktivt til i en artikel i nærværende nummer af Sakprosa. Jeg tror man kan sige at Andersen og jeg er på samme overordnede linje i vores forståelse af politisk debat, men hun har også nogle forbehold og korrektioner. De handler dels om min opfattelse af Habermas' teori om kommunikation, dels nogle af de kriterier som jeg i bogen opstiller for den normative bedømmelse af den politiske debat.

Jeg erkender gerne at jeg kan blive meget klogere på hvad Habermas' kommunikationsteori i dens forskellige udviklingsstadier indebærer. Og som Andersen påpeger, synes der at være en udvikling i Habermas' syn på kommunikation, hvor han bevæger sig bort fra en opfattelse som minder om en jeg kritiserer i min bog. Det gælder bl.a. med hensyn til hvad der ligger i begrebet "strategisk handling". Derfor er det meget sandsynligt at det jeg vender mig imod, i hvert fald ikke svarer til hvad Habermas mener i de senere faser af sin tænkning. I Theorie des kommunikativen Handelns fra 1981 finder vi imidlertid, som Andersen også skriver, at begrebet "strategisk handling” “omfatter all kommunikasjon som har til hensikt å påvirke”. Den definition kan jeg godtage - men jeg tager til gengæld afstand fra at man generelt skal se negativt på sproghandlinger hvorom der gælder dette. Der behøver ikke at være noget galt med strategisk sproglig handling - retorik, kan man sige, er efter sit væsen strategisk.

I hvor høj grad Habermas faktisk har en sådan generelt negativt bedømmelse af "strategisk handling" med sproget, eller om han har haft den, men senere er gået bort fra den i en eller anden grad, er ikke afgørende for mig, og jeg er sikker på at Andersen (og Sine Halkjelsvik Bjordal, som hun citerer) har bedre 
indsigt i dette spørgsmål end jeg. Andersen mener at jeg overdriver min karakteristik af den habermas'ske afstandtagen fra "strategiske" sproghandling, og det kan sagtens være, men hun medgiver at "at Habermas foretrekker den kommunikative handlingstypen fremfor den strategiske”.

\section{Sproget skal påvirke}

Hovedsagen er at jeg mener det er en vildfarelse at have en generelt negativ bedømmelse af sproghandlinger hvori man stræber efter at påvirke andre. Jeg vil gå så vidt som at sige at hvis ikke den grundlæggende motivation bag det meste af vor sproglige handlen var at påvirke andre, så er det usandsynligt at sproget overhovedet ville være opstået. Hvorfor skulle mennesker gøre sig den ulejlighed at udvikle sproget, lære at tale og fremsætte ytringer hvis ikke de ønskede at opnå noget med det?

Men i store dele af filosofien er der, med grundlag i Platon og Kant, en traditionel, stærk uvilje imod sproglig interaktion der søger at påvirke andre ved at skabe lidenskab, trang, eller blot motivation hos andre - dermed gør man nemlig vold på den grundtanke at hvis et menneske vil bruge sin fornuft, er det alene påvirket af sin egen frie vilje . Den politiske teoretiker Bryan Garsten, der har forsvaret retorikken som den deliberative tænknings bedste medium (2006, 2011), gengiver dette kantianske synspunkt sådan: "Reason itself is conceived of as spontaneous and uncaused. If we reason with someone else we do not thereby infringe upon their freedom; instead we invite them to participate with us in the realm of freedom." $(2011,167)$. Og Garsten mener at noget af denne generelle mistænksomhed over for det at virke på andre med sproget har Habermas arvet fra Kant og videreført. Som retoriker kan man ikke dele den - uanset at Andersen skriver, sikkert med rette: "Påstander av typen «Habermas mener...» vil derimot alltid være tvilsomme”. 
Andersens næste (moderate) forbehold over for min fremstilling gælder også et punkt ved min forståelse af Habermas, nemlig med hensyn til om han går ind for ideen om at en ægte kommunikativ samtale vil føre til (eller i retning af) konsensus. Også her har Bjordal leveret en mere præcis forståelse af den tyske filosof: Habermas har således i Faktizität und Geltung fra 1992 anerkendt at det moderne samfunds kompleksitet ofte vanskelig- eller umuliggør konsensus. Denne korrektion er jeg glad for, men jeg vil stadig fastholde at der er flere gode grunde til at konsensus ikke kan forventes, ud over samfundets kompleksitet. Habermas' modstykke i amerikansk tænkning, John Rawls, har efter min mening leveret en præcis forståelse af hvad disse andre faktorer er, idet han taler om "the burdens of reason" (1989) eller "the burdens of judgement” (1993) - derunder at der i en given omstridt sag er forskellige typer af grunde der fremføres fra de stridende parter, og at disse grunde af forskellige individer tillægges forskellig vægt. Det er blandt andet netop disse forhold der gør at konsensus godt nok kan være et mål i tilfælde af politisk uenighed, men at den ikke kan påregnes. F.eks. kan en etisk norm stå over for en økonomisk betragtning (det er to forskellige typer af grunde), og individ A tillægger den ene mest vægt, mens individ B tillægger en anden mest vægt. Og dette er "legitimt, mener jeg - i den forstand at ingen af dem principielt eller objektivt kan siges at "tage fejl”; det er det jeg mener med udtryk som "legitimate dissensus" (Kock 2007) eller "fornuftig uenighed", der er en direkte oversættelse af Rawls' begreb "reasonable disagreement”.

\section{Enighed om fakta?}

Den næste indvending fra Andersen gælder denne principielle norm: "der skal gerne være enighed om fakta, dvs. om hvor man er. Ellers taler man i blinde når man diskuterer i hvilken retning man skal gå” (Kock, 2013 [2011], 62). Andersen er med på at dette ofte er et problem der er med til at gøre debat unyttig, men hun fastholder at “ i mange tilfeller er det urimelig å kreve at 
politikerne skal kunne enes om hvor vi er. Et eksempel er spørsmålet: Er Norge er et egalitært eller klassedelt samfunn?”.

Her er jeg faktisk igen helt enig. Når man bruger begreber som f.eks. "klassedelt samfund", har vi at gøre med sprog som i høj grad er argumenterende i sig selv (det indeholder "framing"), og det kan kun i meget ringere grad, og på uklar vis, fungere referentielt. Sådanne ord og betegnelser har typisk en "argumentativ orientering", for at bruge et udtryk fra den franske lingvist og argumentationstænker Oswald Ducrot: Med et sådant ord signalerer man tydeligt at det som ordet hæftes på, er noget man anser for dårligt, hvorimod man ikke udsiger klart hvilke objektivt konstaterbare egenskaber man mener at det omtalte emne har (man siger ikke noget der har konkrete "sandhedsbetingelser", som en logiker ville sige). Og derfor bliver ordet bestridt af éns politiske modstander. Dermed har de to parter hver for sig signaleret nogle af deres politiske værdier, og det er også vigtigt og uundværligt i politisk debat.

Jeg er ganske enig i Andersens analyse - og jeg må så erkende at jeg har udtrykt mig for ensidigt. Jeg har sigtet til at politikere ofte bruger forskellige, modstridende eller forvirrende tal og faktaudsagn om de samme forhold f.eks. "hvor meget bruger den danske stat på forskning". Problemet er ikke at nogen af parterne taler usandt, men at de typisk definerer det de taler om, på forskellig måde (f.eks. med hensyn til hvad de medregner under forskning betalt af staten) - eller at de mangler at klargøre forudsætningerne for tallene, eller andet; netop den slags problemer har været i centrum for den amerikanske retoriker Kathleen Jamiesons arbejde både med websitet Factcheck.org og i en række publikationer. Og som det fremgår, er Andersen og jeg også ret enige om at kritisere den art tilfælde af faktuel tilsløring eller misvisning. 


\section{Særinteresserne og det fælles bedste}

Et fjerde forbehold gælder min opfattelse om at man i offentlig debat bør fremføre argumenter "som kan aksepteres av de fleste", og som gælder det fælles bedste - altså ikke argumentere ud fra "særinteresser". Andersen nævner eksempler på at f.eks. LO netop argumenterer ud fra særinteresser, og hun mener at det er legitimt - ligesom når LO’s modpart, arbejdsgiverne, gør det.

Måske har jeg også her udtrykt mig forkert eller uklart. Jeg mener at sådanne "særinteresser", f.eks. fremført af arbejderne eller arbejdsgiverne, legitimt kan fremføres i den politiske debat, jævnsides med argumenter ud fra det "fælles bedste”. Som sagt kan mange forskellige typer af argumenter fremføres legitimt. Jeg mener også at hvis argumenter alene står som udtryk for særinteresser, er de ikke særlig hensigtsmæssige, dvs. ikke ret effektive. Minearbejdernes argumentation over for Mrs. Thatcher i Storbritannien omkring 1980 gik ud på at bevare deres arbejdspladser, kulminerne - skønt de nationaløkonomisk set var urentable. De tabte. De kunne ikke overbevise ret mange om at nationen som helhed skulle følge deres vilje. Men argumentation der handler om én bestemt samfundsgruppes interesser, kan godt være effektiv, ud over at den er legitim. Det er især tilfældet hvis den fremføres som hjemlet af en underliggende etisk eller retfærdighedsbaseret norm. Så er der ikke tale om hvad der umiddelbart har de bedste konsekvenser, f.eks. økonomisk, for samfundet - men om hvad der er rimeligt, retfærdigt, etisk rigtigt. F.eks. gælder det både i Danmark og Norge (antager jeg) at argumentation til fordel for de ældre i samfundet har stor gennemslagskraft og opnår stor hensyntagen ved budgetlægningen. Vi bør behandle de ældre værdigt og generøst, også selvom det ikke nødvendigvis gør nogen "nytte" samfundsøkonomisk - det er betragtningen som mange støtter. Der er tale om et deontisk argument, ikke et konsekvensargument. 
Det er endnu et eksempel på pointen om at i politisk debat krydses mange forskellige typer af argumenter. Sådan er det, og det kan ikke være anderledes. Her er Andersen og jeg også enige. Men jeg fastholder samtidig at argumenter i offentlig debat, både konsekvens- og deontiske argumenter, og eventuelle andre slags (f.eks. æstetiske), for at kunne have vægt i debatten skal anerkendes som relevante argumenter af dem man taler til. Det nytter ikke at fremføre et argument hvis hjemmel man kun selv anerkender. Og jo færre der anerkender dets hjemmel, des mindre relevant er argumentet. Dette princip kalder bl.a. de amerikanske demokratiteoretikere Amy Gutmann \& Dennis Thompson “reciprocitet”. Det indebærer bl.a. at en muslim ikke over for andre end troende muslimer kan argumentere alene med hjemmel i hvad der står i Koranen - lige så lidt som en fundamentalistisk kristen kan argumentere over for andre end trosfæller med at noget (f.eks. homoseksualitet) skal være forbudt fordi det står i Bibelen.

De eksempler på “dårlige” argumenter fra min bog som Andersen citerer, er sikkert ikke tydelige nok. Hvad jeg mener, er at f.eks. en gruppe ikke kan regne med at dens argument vil blive tillagt vægt, bare fordi denne gruppe med sit argument fremfører en særinteresse. Alle grupper har f.eks. den rene særinteresse at de gerne vil have en større del af samfundskagen; men for at et sådant krav skal have en vis vægt, skal man tillige kunne sige - enten at det vil gavne det fælles bedste at imødekomme kravet, eller at vi bør gøre det fordi det er rimeligt, etisk påkrævet, el.l., at gøre det, altså hvis vi fremfører en deontisk hjemmel. Også i 8o’ernes Storbritannien har selv hårdkogte konservative utvivlsomt været enige $\mathrm{i}$ at man skulle udvise et vist menneskeligt hensyn til minearbejderne, simpelthen fordi det ville være uetisk slet ikke at gøre det - men det hensyn har ikke været oplevet som vægtigt nok til ret mange ville bevare de urentable kulminer. 


\section{Skjulte motiver?}

Andersens sidste forbehold gælder min afvisning af at argumenter der spekulerer i modstanderes skjulte motiver. Også dette har jeg fremført på en måske lovlig kategorisk og unuanceret måde. Andersen mener nemlig at "det kan være saklig å peke på vikarierende motiver”, og hun fremfører eksempler herpå som virker rigtige og relevante.

Her tror jeg heller ikke uenigheden mellem Andersen og mig er særlig stor. Hun er vist enig i at den slags argumentation trods alt ofte er irrelevant og måske endda skadelig for den politiske kultur, og at den kan fortrænge mere konsekvens-orienterede og deontiske argumenter. Jeg er på den anden side enig i at det kan være relevant, som i Andersens eksempler, at overveje hvad der fremtidig kan ske, og hvad der kan blive det næste efter at nogen har fået en given politik gennemført - og dét kan man i mangel af reel viden om fremtiden danne sig forestillinger om ved at overveje forslagsstillernes mulige motiver.

Det havde f.eks. været klogt af bl.a. Storbritannien i højere grad at overveje Hitlers mulige motiver i slutningen af 1930'erne - i stedet for at vente og se og satse på "fred i vor tid”. Pointen her er at disse spekulationer kan være kilde til forestillinger om fremtiden, og hvis man ikke har bedre kilder, kan man bruge overvejelser om hvad éns modstander måske eller sandsynligvis har i tankerne at gøre - især hvis han, som Hitler, er magtfuld. De sammensvorne der myrdede Cæsar, gjorde det tilsvarende fordi de regnede med at han havde det motiv (den plan) at ville gøre sig til diktator. Og måske havde de fået ret. Alle de værste spekulationer om Hitlers motiver blev jo også overtruffet af Hitler selv. 
De motivspekulationer som jeg advarer imod, er derimod den slags hvor man f.eks. siger at modstander går ind for højere fartgrænser fordi han selv er "vild med at køre stærkt”; man prøver at tale om modstanderens dårlige egenskaber i stedet for om egenskaber ved hans forslag. Skulle vi ikke hellere diskutere fartgrænser ud fra argumenter om konsekvenser for trafiksikkerhed, miljø, klima, smidig afvikling af trafikken, osv.? Jeg tror som sagt Andersen og jeg egentlig er ret enige her.

Lad mig afslutningsvis sige at jeg ser Andersens artikel som et meget seriøst og relevant bidrag til at fortsætte en debat som jeg er glad for at være med i, og at hendes forbehold i høj grad har fået mig til at se mere klart på konkrete aspekter og nuancer. Jeg håber hendes artikel bliver læst af mange, de vil sikkert også blive klogere.

\section{Referencer}

Garsten B. 2006. Saving Persuasion: A Defense of Rhetoric and Judgment. Cambridge, MA: Harvard Univ. Press

Garsten, Bryan. 2011. "The Rhetoric Revival in Political Theory." Annual Review of Political Science 14: 159-180

Gutmann, Amy, and Dennis Thompson. 1996. Democracy and Disagreement. Cambridge, Mass.: Belknap Press of Harvard University Press

Gutmann, Amy, \& Thompson, Dennis. 2004. Why Deliberative Democracy? Princeton: Princeton University Press

Habermas, J. 1981. Die Theorie des kommunikativen Handelns, Band I: Handlungsrationalität und gesellschaftliche Rationalisierung. Frankfurt am Main: Suhrkamp 
Habermas, Jürgen. 1992. Faktizitat und Geltung: Beitrage zur Diskurstheorie des Rechts und des demokratischen Rechtsstaats. Frankfurt am Main:

Suhrkamp

Jackson, Brooks, \& Kathleen Hall Jamieson. 2004. "Finding Fact in Political Debate." American Behavioral Scientist 48.2: 229-237

Jamieson, Kathleen Hall, and Paul Waldman. 2002. The Press Effect:

Politicians, Journalists and the Stories That Shape the Political World. New York: Oxford University Press, 2002

Kock, Christian. 2007. "Norms of Legitimate Dissensus". Informal Logic 27, $179-196$

Kock, Christian. 2011. De svarer ikke: Fordummende uskikke i politisk debat. Copenhagen: Gyldendal. (Udvidet og opdateret udgave 2013.)

Rawls, John. 1989. "The Domain of the Political and Overlapping Consensus". New York UniversityLaw Review 64: 233-255

Rawls, John. 1993. Political Liberalism. New York: Columbia University Press 